\title{
Venous Thrombosis: Prevalence and Interaction of Risk Factors
}

\author{
F.R. Rosendaal
}

Unıversıty Hospital Leiden, Leıden, The Netherlands

\section{Key Words}

Gene-gene interaction - Gene-environment interaction - Selection and interaction .

Dynamic age-dependent model · Factor $V$

Leiden - Factor VIII - Protein C deficiency

\begin{abstract}
The key to understanding why certain individuals develop deep vein thrombosis at varying times, despite similar risk factors being present, is the realization of the importance of gene-gene and gene-environment interactions between risk factors. The discovery of factor $V$ Leiden and several other coagulation abnormalities, which are now known to be common in the general population, has revolutionized the way in which the aetiology of venous thrombosis is viewed. On the basis of current knowledge, time-dependent models taking account of various forms of interaction have been developed.
\end{abstract}

Copyright@1999 S Karger AG, Basel

\begin{tabular}{ll}
\hline KARGER & $1999 \mathrm{~S}$ Karger AG Basel \\
Fax +41613061234 & $0301-0147 / 99 / 0297-0001 \$ 1750 / 0$ \\
$\begin{array}{l}\text { E-Masl karger@karger ch } \\
\text { www karger com }\end{array}$ & Accessible onlme at \\
www karger com/journals/hae
\end{tabular}

\section{Introduction}

Thrombosis is a multicausal disease involving a variety of risk factors, many of which are common; it is now appreciated that the interaction of multiple risk factors over time determines the risk of thrombosis. It is often overlooked in comparisons between studies that one of the most important of these risk factors is age. In individuals aged less than 20 years, the incidence of venous thrombosis is 1 per 100,000 people; at middle age it is approximately 1 per 1,000 , which is also the overall incidence; thereafter it increases steeply, and in old age approaches $1 \%$ per year.

\section{Risk Factors}

The risk factors for venous thrombosis are now generally classified as either genetic or acquired (table 1). 
Table 1. Main causes of venous thrombosis

\begin{tabular}{lll}
\hline Acquired & Genetic & Mixed \\
\hline Surgery/trauma & Antithrombin deficiency & High levels of Factor VIII \\
Immobilization & Protein C deficiency & Hyperhomocysteinaemia \\
Lupus anticoagulant & Protein S deficiency & \\
Malignancy & Activated protein C & \\
Oestrogen & resistance/Factor V Leiden & \\
Pregnancy/puerperium & Prothrombin 20210A & \\
\hline
\end{tabular}

From Rosendaal [33].

Egeberg [1], in 1965, was the first to establish a hereditary tendency to thrombosis when he recorded an inherited antithrombin deficiency within a family with thrombophilia. In the early 1980s, deficiencies of two natural anticoagulant proteins - protein $C$ and protein $\mathrm{S}$ - were described in familial thrombophilia by Griffin et al. [2] and Schwartz et al. [3], respectively. Over the last 5 years, a variety of coagulation abnormalities predisposing to venous thrombosis have been identified. The first of these, described in 1993 by Dahlbäck et al. [4], was a previously unrecognized mechanism characterized by a poor anticoagulant response to activated protein C (APC), i.e. APC resistance. This was subsequently shown by Bertina et al. [5] in 1994 to be caused by a mutation in blood coagulation factor $\mathrm{V}$, otherwise known as factor $\mathrm{V}$ Leiden. Heterozygous deficiency of the three major natural inhibitors of the procoagulant system - protein $C$, protein $S$ and antithrombin leads to excessive thrombin formation. Other abnormalities leading to gains in function and excesses in the procoagulant system include mutation of the prothrombin (factor II) gene, which is associated with raised plasma concentrations of prothrombin 20210A and an increased risk of thrombosis [6]. Raised concentrations of coagulation factor VIII, possi- bly caused by subtle changes in the regulation of gene activity [7], are also associated with an increased risk of thrombosis [8].

\section{Variation due to Acquired Factors}

Apart from genetic considerations, variations in the risk of venous thrombosis might also be explained by acquired factors or a combination of both acquired and genetic factors. Hyperhomocysteinaemia, which has been found to be associated with venous thrombosis in a number of studies [9-12], is a good example of abnormal plasma concentrations resulting from both genetic and acquired factors. It is also plausible that raised levels of factor VIII and prothrombin reflect a combination of genetic and acquired factors.

\section{Prevalence and Risk Estimates}

Even among patients with thrombosis, deficiencies of protein $\mathrm{C}$, protein $\mathrm{S}$ and antithrombin (the classical deficiencies) are rare. Far more common in the general population are APC resistance, prothrombin 20210A, high concentrations of factor VIII, and hyperhomocysteinaemia. As shown in table $2[6$, 
Table 2. Prevalence of risk factors for thrombosis

\begin{tabular}{lll}
\hline Risk factor & $\begin{array}{l}\text { General } \\
\text { population, } \%\end{array}$ & $\begin{array}{l}\text { Patients with } \\
\text { thrombosis, \% }\end{array}$ \\
\hline Proten C deficiency & $0.2-0.4$ & 3 \\
Proten S deficiency & Not known & $1-2$ \\
Antithrombin deficiency & 0.02 & 1 \\
Factor V Leiden & 5 & 20 \\
Prothrombin 20210A & 2 & 6 \\
High concentration of factor VIII $(>1.500$ IU $/ 1)$ & 11 & 25 \\
Hyperhomocysteinaemia $(>18.5 \mu \mathrm{mol} / \mathrm{l})$ & 5 & 10
\end{tabular}

From Rosendaal [33].

13-18], 5\% of the population have APC resistance as a result of factor $\mathrm{V}$ Leiden $[17,19]$. Factor V Leiden is restricted to Caucasians, and regional differences are high. As shown in the table, factor V Leiden occurs in $20 \%$ of consecutive patients with venous thrombosis $[17,20]$ and increases the risk of thrombosis approximately eightfold among heterozygous carriers [17]. Prothrombin 20210A appears to be a relatively mild risk factor, increasing the risk of thrombosis by two- to threefold [6]. Again, this mutation has largely been reported in the white population [21]. Concentrations of factor VIII exceeding 1,500 IU/l have been detected in $11 \%$ of the general population and in $25 \%$ of thrombotic patients; such levels are associated with a sixfold increased risk of thrombosis as compared with concentrations below $1,000 \mathrm{IU} / \mathrm{l}$ [8].

The burden of deep vein thrombosis in society is largely explained by the latter four abnormalities, each of which is associated with a greater attributable risk than the three classical deficiencies combined. The discovery of factor $V$ Leiden and an assessment of its prevalence in unselected patients with deep vein thrombosis $(20 \%)$, patients with familial thrombosis (50\%) and in the general popula- tion $(5 \%)$ revolutionized the way in which the aetiology of thrombosis was viewed. Now that common risk factors had been identified, it became clear that there must be individuals having more than one risk factor. This realization led to attention being diverted to issues of selection and interaction.

\section{Venous Thrombosis as a Multicausal Disorder}

The demonstration that venous thrombosis is a multicausal disorder is most obvious in children. Although thrombosis is rare in children, in the event of it occurring, a variety of genetic and acquired risk factors are usually present simultaneously $[22,23]$. The multicausality of thrombosis is also true in adults. In fact, for the development of thrombosis, multiple risk factors are a prerequisite.

\section{Selection and Interaction}

Among families with thrombophilia, thrombogenic abnormalities are far higher than in the unselected patient with thrombo- 
Table 3. Age at first thrombosis by origin of patient

\begin{tabular}{lll}
\hline Risk factor & \multicolumn{2}{l}{ Age (years) at first thrombosis } \\
\cline { 2 - 3 } & $\begin{array}{l}\text { patients from } \\
\text { thrombophilic families } \\
(\mathrm{n}=78)\end{array}$ & $\begin{array}{l}\text { consecutive } \\
\text { unselected patients } \\
(\mathrm{n}=105)\end{array}$ \\
\hline Protein C deficiency & 31 & 47 \\
Factor V Leiden & 29 & 43 \\
No defect found & 34 & 46 \\
\hline
\end{tabular}

From [33], with permission. sis. In families with thrombophilia, the main coagulation inhibitors are deficient in $15 \%$ of individuals, prothrombin $20210 \mathrm{~A}$ is evident in nearly $20 \%$, and factor V Leiden occurs in $40-60 \%$. Members of these families are also at higher risk for thrombosis than are other individuals with similar defects $[5,16,24-$ 29]. The most important determinant of an individual's thrombotic risk when comparing patients with the same defect appears to be the way in which they are identified or selected. Comparison between consecutive unselected patients and patients from families with thrombophilia indicates a lower mean age at first thrombosis for thrombophilic patients than for consecutive individuals with thrombosis, regardless of the underlying defect, as shown in table 3 [30].

The severity of thrombotic disease is defined here as the age at onset of the condition; the more severe the thrombotic tendency, the earlier the first thrombotic event occurs. Even in thrombophilic families with no identifiable defect, thrombosis occurs at an early age [31]. Why then does the same disorder with the same molecular basis manifest itself with greater severity in the thrombophilic population than in the unselected population? An explanation of this anomaly was found with the discovery of factor $\mathrm{V}$ Leiden, some 10 years after initial studies with thrombophilic patients had centred on the absence or presence of protein $\mathrm{C}$ deficiency. With the discovery of factor $\mathrm{V}$ Leiden, and further studies in familial thrombophilia, the role of gene-gene interaction and its influence on thrombosisfree survival became apparent.

\section{Gene-Gene Interaction}

It is now appreciated that although thrombosis is multicausal, in families with thrombophilia, it is also multigenic. That is, in each of the families studied, there are a variety of genetic defects. As shown in figure 1, members of families with thrombophilia were found in early studies to be at a high risk of thrombosis if they had protein $\mathrm{C}$ deficiency compared with relatives who did not have the deficiency [28]. Fifty percent of those relatives with protein $\mathrm{C}$ deficiency had thrombosis by the age of 50 years. This suggests that an extremely high risk of thrombosis results from a deficiency in protein C. Some years later, these families were assessed for the newly discovered factor $\mathrm{V}$ Leiden. The presence of factor V Leiden was found to be a common secondary defect in a high number of individuals from these families. Further investigation revealed that the risk of thrombosis was far greater for those family members carrying 
Fig. 1. Thrombosis-free survival in families with thrombophilia due to protein $C$ deficiency (proband excluded) From [33], with permıssion

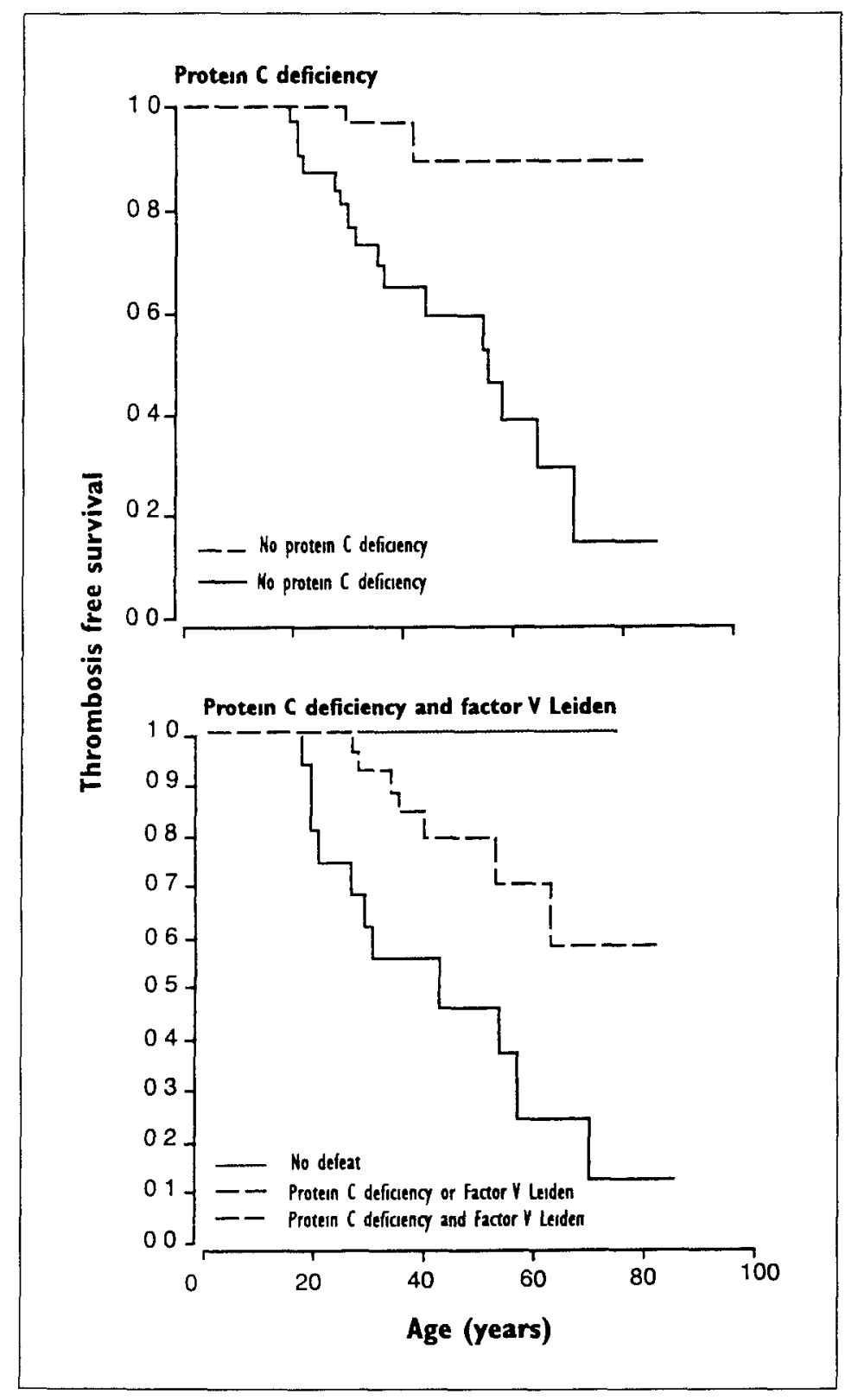

both defects than for those patients carrying protein $\mathrm{C}$ deficiency or factor $\mathrm{V}$ Leiden alone [31]. From these findings it became clear that the thrombosis risk associated with protein $\mathrm{C}$ had been previously overestimated

\section{Gene-Environment Interaction}

A striking example of gene-environment interaction is that relating to the use of oral contraceptives in the presence of factor $\mathrm{V}$ 


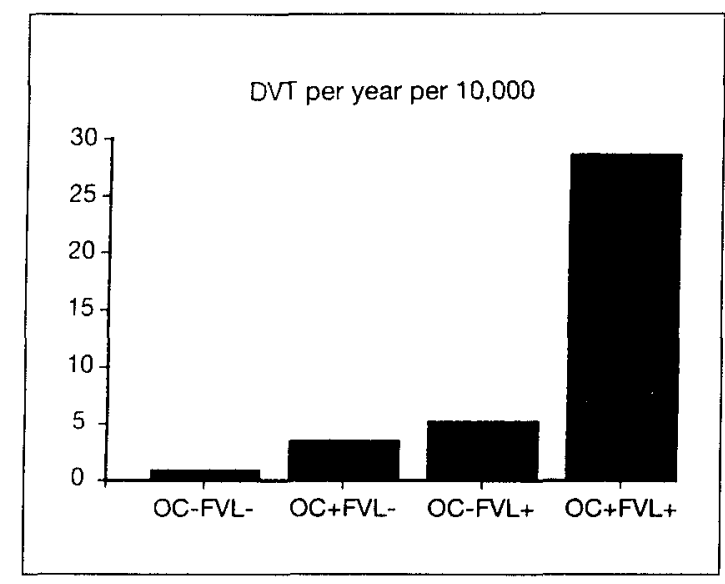

Fig. 2. Gene-environment interaction relating to the use of oral contraceptives in the presence of factor $\mathrm{V}$ Leiden.

Leiden, as shown in figure 2. Among unselected patients, Vandenbroucke et al. [32] revealed a synergistic effect between factor $\mathrm{V}$ Leiden and the use of oral contraceptives. The relative risk of thrombosis in women using oral contraceptives and carrying factor $\mathrm{V}$ Leiden was found to be 34.7 , as compared with 6.9 for women not using oral contraceptives and carrying factor $V$ Leiden. For women using oral contraceptives and not carrying factor $\mathrm{V}$ Leiden, the relative risk of thrombosis was 3.7.

\section{Models of Thrombosis Risk}

The need for a dynamic age-dependent model allowing a variety of forms of interaction of risk factors, such as additive effects or synergism, became evident when even the development of multicausal models, incorporating genetic and acquired risk factors, failed to readily explain why equal numbers of risk factors cause thrombosis in one individual and not in another, or why the same set of risk fac- tors do not cause thrombosis in children but do so in older individuals. An example of a dynamic age-dependent model of this sort is shown in figure 3 .

This model assumes that each risk factor contributes to the risk of thrombosis - this is referred to as the subject's 'thrombosis potential'. In the figure, the black lines indicate the thrombosis potential of each individual risk factor, whereas the grey lines indicate the total thrombosis potential of the individual. The figure traces the progress of a woman with factor V Leiden throughout the course of various events in her life. In the first panel, the risk factors considered are age and factor $\mathrm{V}$ Leiden alone. Here, the thrombosis potential, indicated by a black line, corresponds to that when no other risk factors are encountered throughout her life. The resultant overall lifetime thrombosis potential - following the insertion of an intravenous catheter while a child, the use of oral contraceptives between the age of 20 and 40, and immobilization due to a skiing accident at age 30 - follows a complicated form, and will, as a result of a combination of specific risk factors at a particular age, exceed the thrombosis threshold (shown as a broken and dotted line). As shown in the fifth panel of the figure, the thrombosis threshold is exceeded in our scenario at the age of 30 years, following immobilization, and leads to deep vein thrombosis. It is important to emphasize here that exceeding the threshold does not depend on the number of risk factors present; this same set of risk factors would not have caused thrombosis at age 20. Alternatively, if the woman had not required a plaster cast, but had continued to take oral contraceptives, thrombosis would have occurred at about the age of 50. Finally, at a greater age, the effect of age and factor $\mathrm{V}$ Leiden alone would have been adequate to lead to thrombosis. 


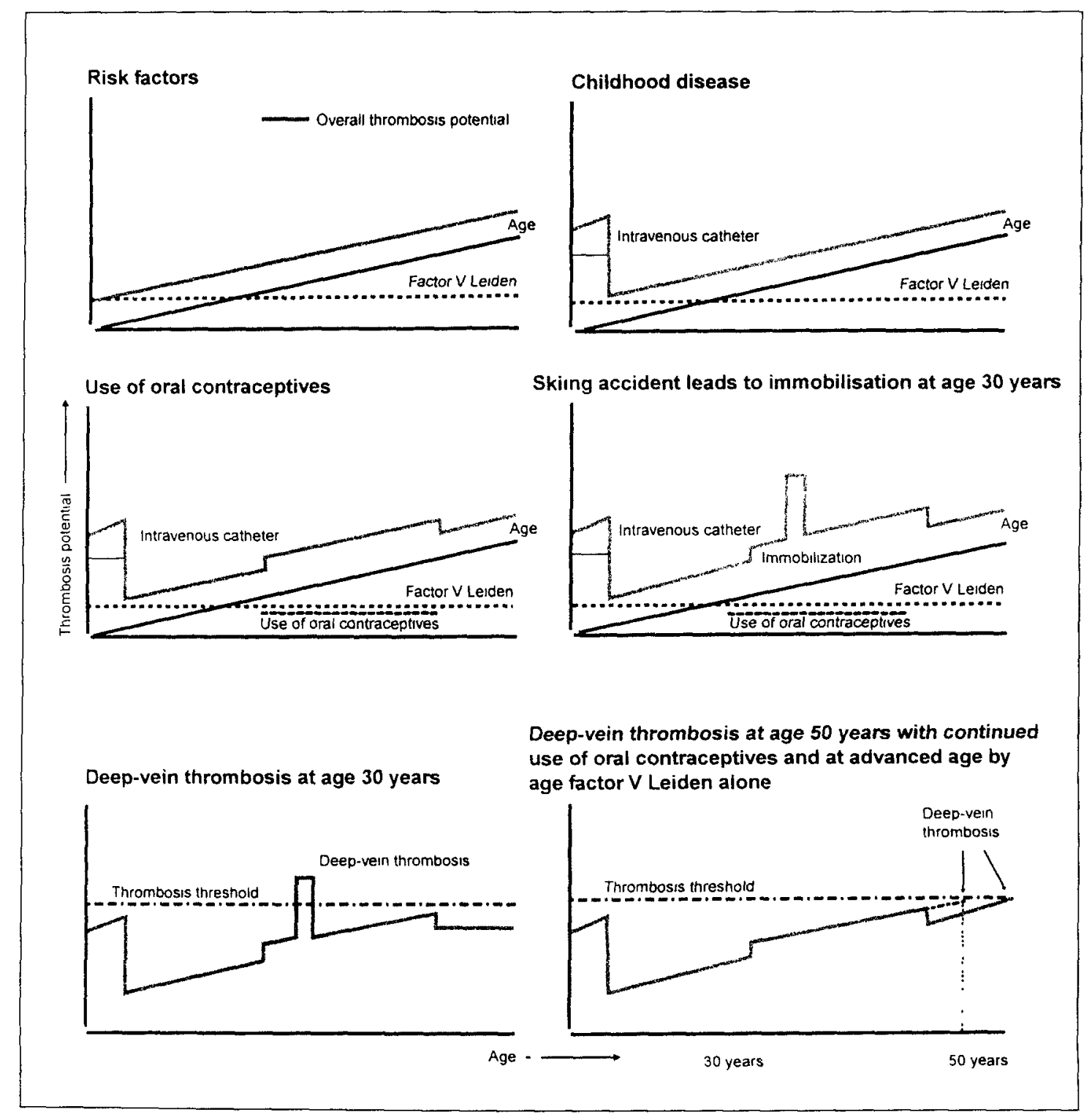

Fig. 3. Models of thrombosis risk. From Rosendaal [33].

In the model described in figure 3 , it is assumed that all the risk factors considered behave in an additive fashion, i.e. without interaction. Figure 4 illustrates a refined model in which the supra-additive effects of factor
$\mathrm{V}$ Leiden and use of oral contraceptives are taken into account. Here it can be seen that a different picture emerges regarding thrombosis potential if interactions of risk factors are taken into account in this way. 
Fig. 4. Models of thrombosis risk with different interactions between factor $V$ Leiden and use of oral contraceptives. From Rosendaal [33].

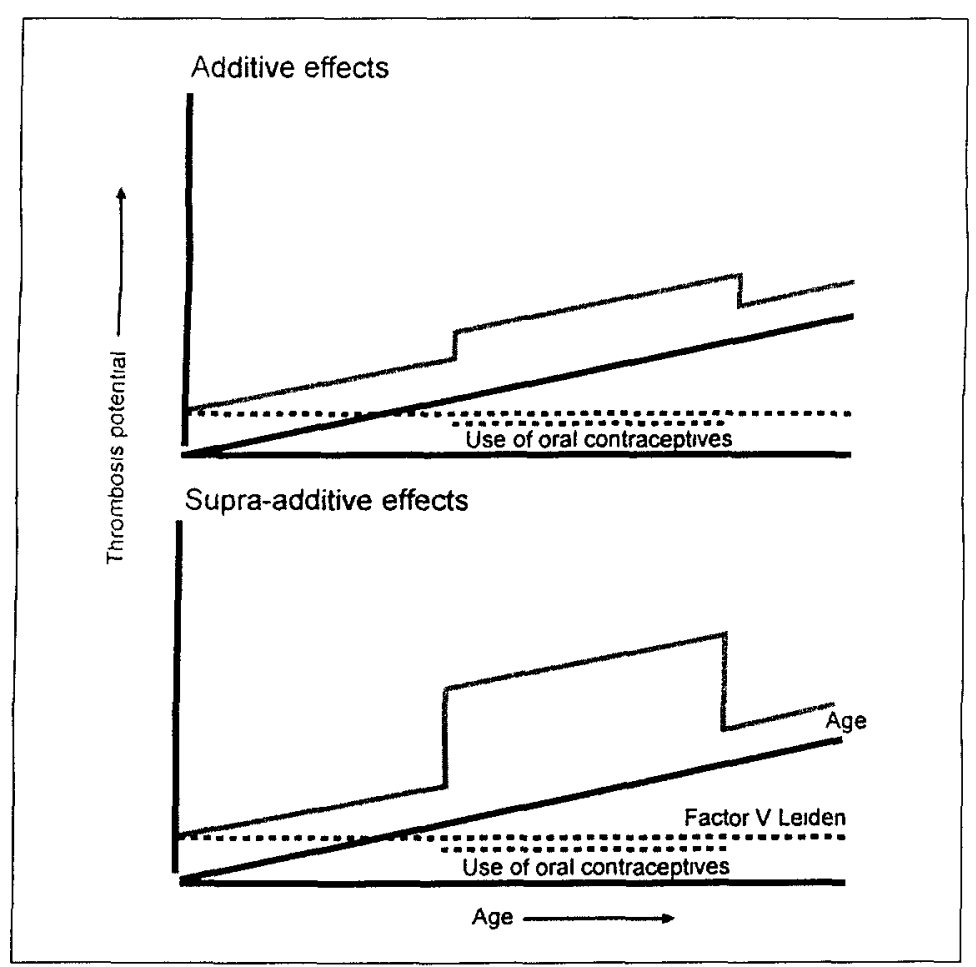

tween risk factors is crucial. Such models explain why thrombosis occurs in an individual at a specific time. In the future, such models may enable the tailoring of individual risk profiles and enable guidelines to be set for prevention and prophylaxis. However, to achieve this, additional information regarding the combined effects of all possible combinations of risk factors will be required.

\section{References}

1 Egeberg O: Inherited ant thrombin deficiency causing thrombophilia. Thromb Diath Haemorrh 1965:13: 516-530.

2 Griffin JH, Evatt B, Zimmerman TS, Kleiss AJ, Wideman C: Deficiency of protein $C$ in congenital thrombotic disease. J Clin Invest 1981:68:1370-1373.
3 Schwartz HP, Fischer M, Hopmeier P, Batard MA, Griffin JH: Plasma protein $S$ deficiency in familial thrombotıc disease. Blood 1984;64: 1297-1300.

4 Dahlbäck B, Carlsson M, Svensson PJ: Familial thrombophilia due to a previously unrecognized mechanism characterized by poor anticoagulant response to activated pro- tein $\mathrm{C}$ : Prediction of a cofactor to activated protein C. Proc Natl Acad Sci USA 1993;90:1004-1008.

5 Bertina RM, Koeleman RPC, Koster T, Rosendaal FR, Dirven RJ, de Ronde $\mathrm{H}$, van der Velden PA, Reitsma PH: Mutation in blood coagulation factor $\mathrm{V}$ associated with resistance to activated protein C. Nature 1994:369:64-67.

8 Haemostasts 1999.29(suppl 1)1-9 
6 Poort SR Rosendaal FR Reitsma PH Bertina RM A common genetic iarsation in the 3 -untranslated region of the prothrombin gene is associatcd with elevated plasma prothrombin levels and an increase in venous thrombosis Blood 199688 3698-3703

7 Kamphuisen PW Houwing.Duistermmaat $J \boldsymbol{J}$ van Houwelingen $J C$ Eıkenboom JC Bertına RM Rosendaal FR Familial clustering of factor VIII and von Willebrand factor levels Thromb Haemost 199879 323-327

8 Koster $T$ Blann AD Briet $E$ Vandenbroucke JP Rosendaal FR Role of clotting factor VIII in effect of ion Willebrand factor on occurrence of deep-vein thrombosis Lancet 1995345 I52-155

9 Bicnvenu $\mathrm{T}$ Ankrı A Chadefaux B Kamoun P Plasma homocystem assat in the exploration of thrombosis In voung subjects Presse Med 1991 20 985-988

10 Falcon CR Cattaneo M Panzen D Martineli I Mannucci PM High prevalence of hyperhomocyst(e)inemia in patients with juvenile renous thrombosis Arterioscler Thromb 199414 1080-1083

11 Simıon P Prandonı P Burlina A Tormene D Sardella C Ferrarı V Bunedett L Girolamı A Hyperhomocvstememia and deep-vern thrombosis A case-control study Thromb Haemost $199676883-$ 886

12 Den Heijer M Koster T Blom HJ Bos GM Briet E Reitsma PH Vandenbroucke JP Rosendaal FR Hyperhomocystememia as a risk factor for deep-vein thrombosis $N$ Engl $J$ Med 1996334 759-762

13 Rosendaal FR Risk factors for ve. nous thrombosis Prevalence risk and interaction Semin Hemato 199734 171-187

14 Talt RC Walker ID Reitsma PH Islam SI McCall F Poort SR Conkie JA Bertina RM Prevalence of protenn $C$ deficiency in the healthy population Thromb Hacmost 1995 $7387-93$
15 Tait RC Walker ID Perry DJ et al Prevalence of antithrombin deficiency in the healthy population $\mathrm{Br}$ J Haematol 199487 106-112

16 Miletıch J Sherman L Broze G Absence of thrombosis in subjects with heterozygous protein $C$ deficiency N Engl J Med $1987317991-996$

17 Rosendaal FR Koster T Vandenbroucke JP Reitsma PH High risk of thrombosis in patients homozygous for factor $\mathrm{V}$ Leiden (activated proten $C$ reststance) Blood 1995 $851504-1508$

18 Koster T Rosendaal FR Briet E van der Meer FJ Colly LP Trienekens PH Poort SR Reitsma PH Vandenbroucke JP Protem $C$ defi clency in a controlled series of unse lected outpatients An infrequen but clear risk factor for venous thrombosis (Leiden Thrombophilia Study) Blood 199585 2756-2761

19 Rees DC Cox M Clegg JB World distribution of factor V Leiden Lancet $19953461133-1134$

20 Koster T Rosendaal FR De Ronde $H$ Briet E Vandenbroucke JP Ber tuna RM Venous thrombosis due to a poor anticoagulant response to ac tivated protein C Leiden Thrombophilsa Study Lancet 1993342 1503-1506

21 Rosendaal FR Doggen CJM Zıve In A Arruda VR Aiach M Sisco vick DS Hillarp A Watzke $\mathrm{HH}$ Bernardı F Cumming AM Preston FE Reitsma PH Geographic distr bution of the $20210 \mathrm{G}$ to A prothrombin variant Thromb Haemost $199879706-708$

22 Andrew M, Dand M Adams M Al $\mathrm{K}$ Anderson $\mathrm{R}$ Barnard $\mathrm{D}$ Bernstein M Brisson L Cairney B DeSal D Venous thromboembolic complications (VTE) in children First analyses of the Canadian regis try Blood 199483 1251-1257

23 Nuss R Hays T Manco-Johnson M Childhood thrombosis Pediatrics $199596291-294$

24 Tabernero MD Tomas JF Alberca I Orfao A Lopez Borrasca A V1cente $\mathrm{V}$ Incidence and clmical characteristics of hereditary disorders associated with venous thrombosis Am J Hematol 199136 249-254
25 Griffin JH Evatt B Wideman C Fernandez JA Anticoagulant protein $C$ pathway defective in a majorit $v$ of thrombophilic patients Blood 199382 1989-1993

26 Scharrer I Hach-Wunderle V Heyland $H$ Kuhn $C$ Incidence of defective t-PA release in 158 unrelated young patients with venous thrombosis in comparison to PC- PS- AT III- fibrinogen- and plasminogen deficiency Thromb Haemost 1987 5872

27 Ben Tal O Zivelın A Selıgsohn U The relatuve frequency of hereditary thrombotic disorders among $107 \mathrm{pa}$ tlents with thrombophilia in Israel Thromb Haemost 198961 50-54

28 Allaart CF Poort SR Rosendaal FR Retsma PH Bertina RM Briet $E$ Increased risk of venous thrombosis in carriers of protein $C$ deficiency defect Lancet 1993341 134-138

29 Tsuda S Reitsma P Miletich J Mo lecular defects causing heterozygous proten $C$ deticiency in three asymptomat $1 \mathrm{c}$ kindreds Thromb Haemost 199165647

30 Lensen RPM Rosendaal FR Koster $T$ Allart CF de Ronde H Vandenbroucke JP Rcitsma PH Bert1na RM Apparent different thrombotic tendency in patients with factor $V$ Leiden and protein $C$ deficiency due to selection of patients Blood $1996884205-4208$

31 Koeleman BPC Reitsma PH Allaart CF Bertına RM APC-resistance as an additional risk factor for thrombosts in protesn $C$ deficient families Blood 1994841031 1035

32 Vandenbroucke JP Koster T Briet E Reitsma PH Bertına RM Rosendaal FR Increased risk of venous thrombosis in oral contraceptive users who are carriers of factor V Lc1den mutation Lancet 1994344 1453-1457

33 Rosendaal FR Venous thrombosis A multicausal disease Lancet 1999 $3531167-1173$ 